\title{
Karakteristik Tanaman Sorghum Green Fodder (SGF) Hasil Penanaman Secara Hidroponik yang Dipanen pada Umur yang Berbeda
}

\author{
Teguh Wahyono', Husnul Khotimah ${ }^{2}$, Widhi Kurniawan ${ }^{3}$, Dedi Ansori ${ }^{1}$, Anna Muawanah ${ }^{2}$ \\ ${ }^{1}$ Pusat Aplikasi Isotop dan Radiasi, Badan Tenaga Nuklir Nasional \\ Jl. Lebak Bulus Raya No. 49, Cilandak, Jakarta Selatan 12070 \\ ${ }^{2}$ Fakultas Sains dan Teknologi, Universitas Islam Negeri Syarif Hidayatullah \\ Jl. Ir. H. Juanda No. 95, Ciputat, Banten \\ ${ }^{3}$ Fakultas Peternakan, Universitas Halu Oleo \\ Jl. H.E.A. Mokodompit Kampus Hijau Bumi Tridharma, Anduonohu, Kendari 93232 \\ *Email korespondensi: teguhwahyono@batan.go.id
}

(Diterima: 25-02-2019; disetujui 10-04-2019)

\begin{abstract}
ABSTRAK
Tanaman sorgum yang dibudidayakan secara hidroponik dapat disebut dengan Sorghum Green Fodder (SGF). Penelitian ini bertujuan untuk melakukan evaluasi performa pertumbuhan, profil nutrisi dan kecernaan in vitro tanaman sorgum hasil budidaya hidroponik yang dipanen pada umur yang berbeda. Perlakuan penelitian meliputi SGF yang dipanen pada hari ke 7, 8, 9, dan 10. Pada pengamatan kecernaan in vitro, keempat perlakuan SGF dibandingkan dengan rumput lapangan. Penelitian ini menggunakan Rancangan Acak Lengkap dengan empat pengulangan. Parameter yang diamati adalah performa pertumbuhan, profil nutrisi, produksi gas dan produk fermentasi rumen. Hasil penelitian menunjukkan bahwa SGF 10 menghasilkan tinggi tanaman dan berat segar tertinggi $(\mathrm{P}<0,05)$ namun tidak berbeda nyata dengan SGF 9. Kandungan protein kasar SGF lebih tinggi dibandingkan rumput lapangan $(\mathrm{P}<0,05)$. SGF menghasilkan produksi gas total yang lebih tinggi dibandingkan rumput lapangan $(\mathrm{P}<0,05)$. SGF 10 menghasilkan produksi $\mathrm{CH}_{4}$ yang tinggi. Nilai energi termetabolis (EM) dan kecernaan bahan organik (KcBO) keempat perlakuan SGF terlihat lebih tinggi dibandingkan rumput lapangan $(\mathrm{P}<0,05)$. Kesimpulan dari penelitian ini adalah pola pertumbuhan, profil nutrisi dan kecernaan in vitro SGF semakin meningkat seiiring dengan meningkatnya umur pemanenan. Umur panen SGF yang terbaik adalah pada hari ke-9.
\end{abstract}

Kata Kunci: hidroponik, in vitro, profil nutrisi, sorghum green fodder

\begin{abstract}
Sorghum Green Fodder (SGF) was sorghum plants cultivated by hydroponic methods. This experiment was designed to evaluate the growth performance, nutrient profile and in vitro digestibility of SGF harvested at different phases. Sorghum Green Fodders were harvested on the 7th, 8th, 9th and 10th days following sowing date. All for SGF treatments were compared with native grass in the observation of in vitro digestibility. Experimental design was completely randomized design with four replications. Analyses performed for growth performance, nutrient profiles, in vitro gas production and rumen fermentation products. The results showed that SGF 10 produced the highest plant height and fresh weight ( $\mathrm{P}<0.05)$, but not different with SGF 9. The crude protein content of SGF was higher than native grass ( $\mathrm{P}$ $<0.05)$. SGF produces the higher total gas production than native grass $(\mathrm{P}<0.05)$. However, SGF 10 also produces high $\mathrm{CH}_{4}$ production. The matabolisable energy (ME) and organic matter digestibility of the all SGF treatments were higher than native grass $(\mathrm{P}<0.05)$. According to the results, the pattern of growth performance, nutrient profile and in vitro digestibility of SGF are increasing along with the increasing of harvesting age. SGF harvested at $9^{\text {th }}$ had a good quality for fodder.
\end{abstract}

Keywords: hidroponics, in vitro, nutrient profile, sorghum green fodder 


\section{PENDAHULUAN}

Hijauan pakan yang berkualitas baik merupakan kebutuhan pokok yang sulit dipenuhi bagi peternakan rakyat di Indonesia. Kendala yang semakin meningkat adalah adanya alih fungsi lahan produktif pertanian menjadi lahan industri dan perumahan. Permasalahan perubahan iklim juga turut mempengaruhi kualitas dan kuantitas produksi hijauan pakan. Berdasarkan beberapa tantangan tersebut, diperlukan metode alternatif yang revolusioner untuk mengatasi permasalahan penyediaan hijauan pakan di lahan terbatas dan ketidakpastian iklim. Chrisdiana (2018) menjelaskan bahwa hidroponik adalah teknik budidaya hijauan pakan yang cocok diaplikasikan untuk mengatasi kendala ketergantungan iklim dan ketersediaan lahan. Hijauan pakan yang dibudidayakan secara hidroponik sering disebut dengan hydroponic green fodder. Budidaya hijauan pakan secara hidroponik dilakukan dalam periode yang singkat, hanya menggunakan media cair dan dilakukan di lingkungan yang terkontrol (Wahyono et al., 2018).

Beberapa penelitian sebelumnya telah melaporkan berbagai kelebihan hydroponic green fodder. Wahyono et al. (2018) melaporkan bahwa hydroponic green fodder mengandung nutrisi yang tinggi dan rendah cemaran bahan berbahaya bagi ternak. Kumalasari et al. (2017) juga melaporkan bahwa hijauan pakan hasil budidaya hidroponik mengandung protein kasar yang tinggi dan serat yang lebih rendah dibandingkan hijauan yang ditanaman secara konvensional. Zahera et al. (2015) menjelaskan bahwa hijauan pakan yang ditanam secara hidroponik menghasilkan kecernaan yang tinggi $(>80 \%)$. Tanaman serealia (jagung, gandum, barley dan sorghum) merupakan jenis tanaman yang banyak dibudidayakan secara hidroponik sebagai pakan ternak. Sorgum adalah tanaman yang potensial dikembangkan sebagai green fodder karena berkembang baik di lingkungan tropis dan efisien dalam menghasilkan produk fotosintesis (Chrisdiana, 2018).

Tanaman sorgum yang dibudidayakan secara hidroponik dapat disebut dengan Sorghum Green Fodder (SGF). Beberapa riset di Indonesia yang menggunakan topik sorgum sebagai green fodder telah dilakukan sebelumnya oleh Chrisdiana (2018) dan Wahyono et al. (2018). Fazaeli et al. (2012) dan Akbag et al. (2014) melaporkan bahwa kandungan nutrisi dan kecernaan hijauan pakan hasil budidaya hidroponik dipengaruhi oleh fase/umur pemanenan. Studi tentang pengaruh umur panen terhadap profil nutrisi dan kecernaan sorgum yang dibudidayakan secara hidroponik belum banyak dilakukan di Indonesia. Oleh karena itu, tujuan dari penelitian ini adalah untuk melakukan evaluasi profil pertumbuhan, profil nutrisi dan kecernaan in vitro tanaman sorgum hasil budidaya hidroponik yang dipanen pada umur yang berbeda.

\section{MATERI DAN METODE}

\section{Persiapan Benih}

Benih sorgum (Sorghum bicolor (L.) Moench) yang digunakan adalah sorgum varietas Samurai 2. Benih sorgum diperoleh dari bidang Pertanian, Pusat Aplikasi Isotop dan Radiasi, BATAN. Samurai 2 adalah varietas sorgum hasil penelitian pemuliaan tanaman menggunakan aplikasi mutasi radiasi.

\section{Metode Penelitian}

Penelitian ini menggunakan Rancangan Acak Lengkap dengan empat pengulangan. Model penelitian adalah: Yij $=\mu+\alpha i+\varepsilon i j$; Yij adalah hasil observasi pada perlakuan ke-i dan ulangan ke-j, $\mu$ adalah rerata umum, $\alpha \mathrm{i}$ adalah efek perlakuan ke-i dan eij adalah efek random. Pengamatan pertumbuhan SGF dan evaluasi produksi gas secara in vitro dilakukan pada penelitian ini. Perlakuan penelitian meliputi SGF yang dipanen pada hari ke 7, 8, 9 dan 10. Evaluasi produksi gas secara in vitro dilakukan kepada seluruh perlakuan SGF yang dibandingkan dengan rumput lapangan. Analisis statistik dilakukan menggunakan perangkat SPSS 22.0. Perbedaan antar perlakuan diamati berdasarkan uji Duncan's Multiple Range Test (Steel \& Torrie, 1960).

\section{Penanaman Menggunakan Sistem Hidroponik}

Instalasi penanaman SGF secara hidroponik dapat dilihat pada Gambar 1. Perangkat penanaman dibuat pada rak baja yang terdapat dalam ruangan steril dengan sistem irigasi otomatis. Kapasitas penanaman adalah sepuluh nampan polyethylene masing-masing berukuran $60 \times 18 \mathrm{~cm}$. Model perangkat hidroponik adalah nutrient film technique system (Lee \& Lee, 2015). Temperatur ruangan diatur pada suhu $20-22^{\circ} \mathrm{C}$ dengan kelembaban $60-70 \%$. Benih sorgum disterilisasi menggunakan 5,25\% larutan natrium hipoklorit. 
Benih yang telah bersih, direndam selama 24 jam kemudian disebar ke dalam masing-masing nampan polyethylene sesuai perlakuan. Kepadatan benih adalah sekitar $0,38 \mathrm{~g} / \mathrm{cm} 2$. Sistem irigasi dilakukan secara otomatis menggunakan digital timer. Periode irigasi dilakukan setiap dua jam sekali, selama dua menit pada masing-masing waktu pengairan. Irigasi dilakukan menggunakan larutan nutrisi hidroponik pada hari pertama dilanjutkan air bersih pada hari berikutnya. Pada hari pertama-kedua, nampan polyethylene ditutup menggunakan plastik hitam untuk mendukung perkecambahan benih.

\section{Preparasi Sampel}

Sorghum green fodder dipanen pada umur ke 7, 8, 9 dan 10. Penampakan SGF pada setiap umur panen dapat dilihat pada Gambar 2. Data pertumbuhan yang diamati adalah berat segar $(\mathrm{kg})$, tinggi tanaman $(\mathrm{cm})$, rasio konversi (SGF:biji), bahan kering (BK, \%) dan bahan organik (BO, \%). Sampel SGF segar dikeringkan pada oven $600 \mathrm{C}$ selama 48 jam. Sampel kering digiling halus sampai berukuran $\pm 1 \mathrm{~mm}$. Preparasi yang sama juga dilakukan pada sampel rumput lapangan yang diperoleh dari sekitar kebun percobaan Bidang Pertanian PAIR BATAN. Kandungan nutrisi sampel pakan yang diamati meliputi kandungan protein kasar (PK), lemak kasar (LK) (AOAC, 2005), neutral detergent fiber (NDF) dan acid detergent fiber (ADF) (Van Soest et al., 1991).

Sampel cairan rumen untuk uji in vitro diperoleh dari kerbau jantan berfistula yang diberi ransum pakan konsentrat dan rumput lapangan (30:70\% dalam BK). Ransum pada kerbau diberikan dua kali sehari. Koleksi cairan rumen diperoleh dari bagian tengah rumen.

\section{Evaluasi Produksi Gas secara In vitro}

Cairan rumen disaring menggunakan kain kassa empat lipatan. Syringe glass diinkubasi pada waterbath bersuhu $39^{\circ} \mathrm{C}$ sebelum digunakan. Sebanyak $380 \mathrm{mg}$ sampel (dalam BK) diinkubasi dalam syringe glass (Fortuna model, Germany; Kapasitas $100 \mathrm{ml}$ ) yang berisi $40 \mathrm{ml}$ cairan rumenbuffer. Metode yang digunakan berdasarkan Menke et al. (1979) yang dimodifikasi Blümmel et al. (1997). Inkubasi dilakukan pada waterbath bersuhu $39^{\circ} \mathrm{C}$ selama 48 jam. Pengamatan dilakukan sebanyak empat kali pengulangan. Parameter yang diamati meliputi produksi gas total (ml/380 mg BK), konsentrasi $\mathrm{CH}_{4}(\%), \mathrm{pH}$, ammonia $\left(\mathrm{NH}_{3}\right)(\mathrm{mg} / 100 \mathrm{ml})$, total volatile fatty acids (TVFA) (mM), energi yang termetabolis (EM) $(\mathrm{kkal} / \mathrm{kg} \mathrm{BK})$ dan kecernaan bahan organik $(\mathrm{KcBO})(\%)$.
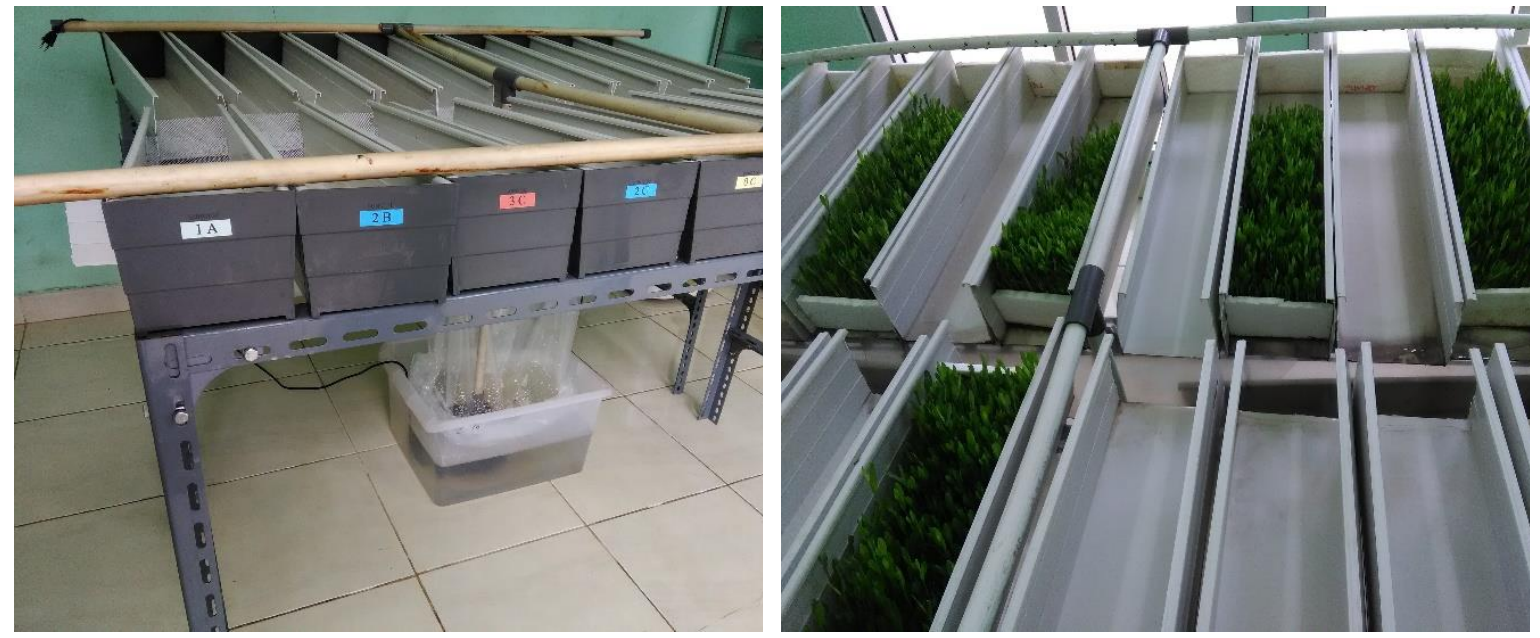

Gambar 1. Instalasi penanaman sorghum green fodder 


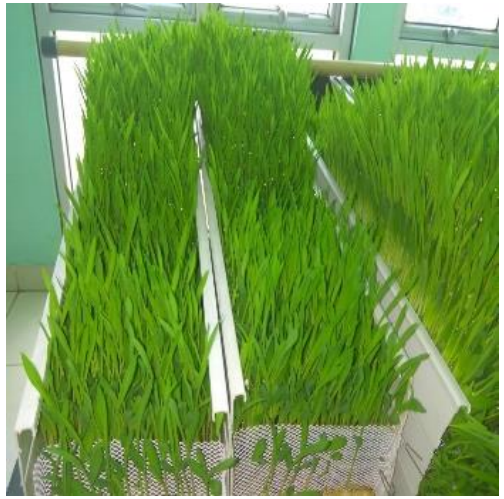

(a)

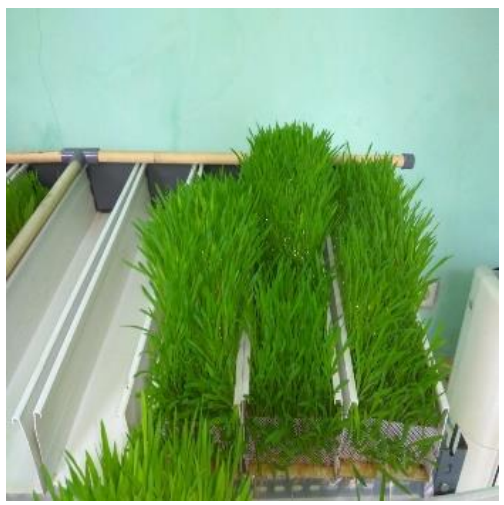

(c)

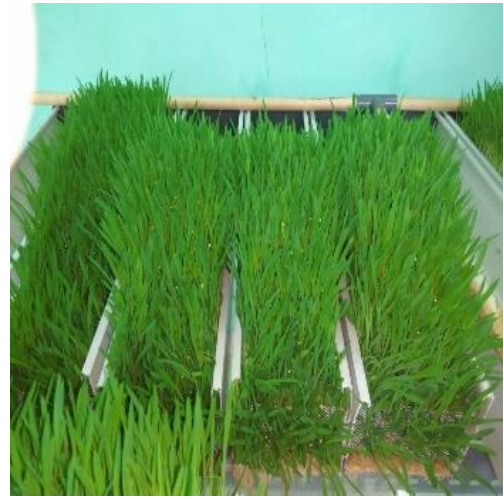

(b)

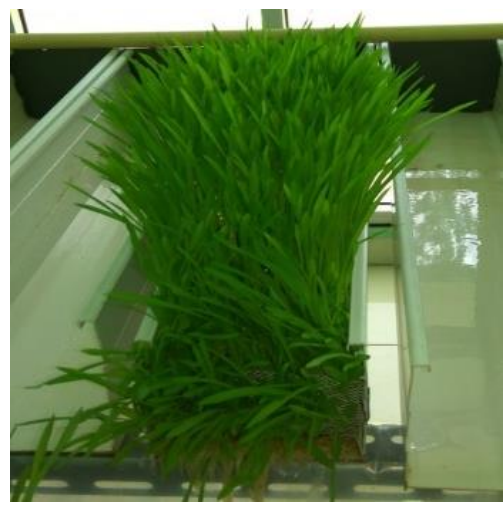

(d)

Gambar 2. Penampakan Sorghum Green Fodder berdasarkan umur panen.

(a) umur panen 7 hari, (b) 8 hari, (c) 9 hari dan (d) 10 hari

\section{Pengamatan Produk Fermentasi Rumen}

Produksi gas diamati pada waktu inkubasi ke-2, 4, 6, 8, 10, 12, 24 dan 48 jam. Konsentrasi $\mathrm{CH}_{4}$, produksi $\mathrm{CH}_{4}, \mathrm{pH}, \mathrm{NH}_{3}, \mathrm{TVFA}, \mathrm{EM}$ dan KcBO diamati setelah 48 jam inkubasi. Pengukuran gas $\mathrm{CH}_{4}$ dilakukan menggunakan MRU gas Analyzer®. Pengukuran $\mathrm{pH}$ menggunakan $\mathrm{pH}$ meter Hanna instrument ${ }^{\circledR}$. Pengukuran $\mathrm{NH}_{3}$ menggunakan metode mikrodifusi Conway. Pengukuran TVFA berdasar prosedur dalam AOAC (2005). Perhitungan EM and $\mathrm{KcBO}$ dilakukan berdasarkan rumus dalam Menke et al. (1979):

$$
\mathrm{EM}(\mathrm{MJ} / \mathrm{kg} \mathrm{BK})=2,20+0,136 \mathrm{PG}+0,057 \mathrm{PK}
$$

$$
\mathrm{KcBO}(\%)=4,88+0,889 \mathrm{PG}+0,45 \mathrm{PK}+0,0651 \mathrm{abu}
$$

PG adalah produksi gas total pada 24 jam inkubasi. PK adalah kandungan protein kasar. EM dikonversi kedalam $\mathrm{kkal} / \mathrm{kg} \mathrm{BK}$.

\section{HASIL DAN PEMBAHASAN}

\section{Performa Pertumbuhan}

Performa pertumbuhan SGF dapat dilihat pada Tabel 1. Perlakuan SGF 10 menghasilkan ukuran tanaman yang paling tinggi $(\mathrm{P}<0,05)$ namun tidak berbeda nyata dengan SGF 9, demikian pula dengan peubah nilai berat segar, rasio konversi, bahan kering dan bahan organik.

Nilai tinggi tanaman dan berat segar SGF semakin meningkat seiiring dengan bertambahnya umur panen. Hal tersebut akan berpengaruh terhadap peubah rasio konversi antara SGF:biji. Biomassa green fodder akan semakin meningkat seiring dengan meningkatnya umur panen (Chrisdiana, 2018). Rasio batang dan daun akan semakin meningkat sehingga akan meningkatkan berat segar yang merupakan representasi dari biomassa tanaman (Koten et al., 2014). Peningkatan umur panen juga terbukti meningkatkan kandungan bahan kering dan bahan organik SGF. Hal tersebut dipengaruhi oleh 
meningkatnya konversi nutrisi yang diperoleh dari air dan simpanan dalam biji selama proses pemeliharaan. Pertumbuhan tanaman green fodder sangat dipengaruhi oleh ketersediaan nutrisi di dalam biji (Chrisdiana, 2018).

Hasil dalam penelitian ini kontradiktif dengan hasil penelitian Akbag et al. (2014) dan Fazaeli et al. (2012). Dalam penelitian sebelumnya, kandungan bahan kering dan bahan organik menurun seiring dengan meningkatnya umur panen. Perbedaan hasil ini dapat disebabkan oleh perbedaan komoditas tanaman, penggunaan larutan nutrisi dan penentuan umur panen. Pada penelitian Fazaeli et al. (2012) digunakan barley dan dipanen pada hari ke 6-8, sedangkan dalam penelitian ini digunakan tanaman sorgum yang dipanen pada hari ke 7-10. Chrisdiana (2018) menjelaskan bahwa akar sekunder pada tanaman sorgum baru terbentuk pada hari ke 3-7 setelah perkecambahan. Berbagai faktor lain yang mempengaruhi performa pertumbuhan SGF adalah kualitas biji, frekuensi irigasi, kelembaban dan intensitas cahaya (Wahyono et al., 2018).

Tabel 1. Pola pertumbuhan SGF yang dipanen pada umur yang berbeda.

\begin{tabular}{llllll}
\hline \multirow{2}{*}{ Performa Pertumbuhan } & \multicolumn{5}{c}{ Perlakuan } \\
\cline { 2 - 6 } & SGF 7 & SGF 8 & SGF 9 & SGF 10 & SEM \\
\hline Tinggi tanaman (cm) & $13,17^{\mathrm{a}}$ & $14,42^{\mathrm{ab}}$ & $15,71^{\mathrm{bc}}$ & $16,37^{\mathrm{c}}$ & 0,379 \\
Berat segar (kg) & $1,10^{\mathrm{a}}$ & $1,17^{\mathrm{b}}$ & $1,27^{\mathrm{c}}$ & $1,29^{\mathrm{c}}$ & 0,021 \\
Rasio konversi (SGF:biji) & $5,49^{\mathrm{a}}$ & $5,85^{\mathrm{b}}$ & $6,31^{\mathrm{c}}$ & $6,42^{\mathrm{c}}$ & 0,107 \\
Bahan kering (\%) & $7,55^{\mathrm{a}}$ & $9,10^{\mathrm{b}}$ & $9,72^{\mathrm{c}}$ & $9,74^{\mathrm{c}}$ & 0,210 \\
Bahan organik (\%) & $98,83^{\mathrm{a}}$ & $98,71^{\mathrm{a}}$ & $99,33^{\mathrm{b}}$ & $99,40^{\mathrm{b}}$ & 0,079 \\
\hline
\end{tabular}

SGF (Sorghum Green Fodder); SGF 7 (SGF yang dipanen pada umur 7 hari); SGF 8 (dipanen pada umur 8 hari); SGF 9 (dipanen pada umur 9 hari) dan SGF 10 (dipanen pada umur 10 hari); superskrip berbeda pada kolom yang sama menunjukkan perbedaan yang nyata $(\mathrm{P}<0.05)$; SEM: Standard Error of the Means.

Tabel 2. Profil nutrisi rumput lapangan, biji sorgum dan SGF

\begin{tabular}{llllllll}
\hline \multirow{2}{*}{ Profil Nutrisi } & \multicolumn{7}{c}{ Perlakuan } \\
\cline { 2 - 7 } & Rumput lapangan & Biji & SGF 7 & SGF 8 & SGF 9 & SGF 10 & SEM \\
\hline Protein kasar (\%) & $11,86^{\mathrm{b}}$ & $9,28^{\mathrm{a}}$ & $13,77^{\mathrm{c}}$ & $13,86^{\mathrm{c}}$ & $14,67^{\mathrm{c}}$ & $14,72^{\mathrm{c}}$ & 0,788 \\
Lemak kasar (\%) & $1,77^{\mathrm{a}}$ & $1,77^{\mathrm{a}}$ & $2,73^{\mathrm{ab}}$ & $3,05^{\mathrm{ab}}$ & $3,65^{\mathrm{bc}}$ & $4,53^{\mathrm{c}}$ & 0,236 \\
Neutral detergent fiber (\%) & $83,52^{\mathrm{d}}$ & $46,38^{\mathrm{a}}$ & $58,25^{\mathrm{b}}$ & $59,69^{\mathrm{b}}$ & $61,17^{\mathrm{b}}$ & $68,66^{\mathrm{c}}$ & 2,455 \\
Acid detergent fiber $(\%)$ & $43,27^{\mathrm{d}}$ & $9,60^{\mathrm{a}}$ & $26,67^{\mathrm{b}}$ & $28,39^{\mathrm{bc}}$ & $29,91^{\mathrm{c}}$ & $28,57^{\mathrm{bc}}$ & 2,059 \\
\hline
\end{tabular}

SGF (Sorghum Green Fodder); SGF 7 (SGF yang dipanen pada umur 7 hari); SGF 8 (dipanen pada umur 8 hari); SGF 9 (dipanen pada umur 9 hari) dan SGF 10 (dipanen pada umur 10 hari); superskrip berbeda pada kolom yang sama menunjukkan perbedaan yang nyata $(\mathrm{P}<0.05)$; SEM: Standard Error of the Means.

\section{Profil Nutrisi}

Profil nutrisi berupa kandungan PK, LK, NDF, dan ADF dapat dilihat pada Tabel 2. Kandungan PK SGF yang dipanen pada umur yang berbeda, lebih tinggi dibandingkan rumput lapangan $(\mathrm{P}<0,05)$. Kandungan LK pada SGF 9 dan 10 terlihat 2 kali lebih tinggi dibandingkan rumput lapangan $(\mathrm{P}<0,05)$. Kandungan NDF dan ADF SGF lebih rendah dibandingkan rumput lapangan $(\mathrm{P}<0,05)$. Pola kandungan $\mathrm{NDF}$ pada SGF cenderung meningkat hingga umur panen 10 hari $(\mathrm{P}<0,05)$. Dari keempat peubah profil nutrisi juga terlihat bahwa keempat umur panen SGF menghasilkan nutrisi yang meningkat dibandingkan pada saat berbentuk biji.

Kandungan PK dan LK SGF yang lebih tinggi menandakan bahwa SGF mengandung nutrisi yang lebih baik dibandingkan dengan rumput lapangan. PadaTabel 2 terlihat bahwa secara statistik, waktu panen yang berbeda tidak berpengaruh terhadap kandungan PK. Akan tetapi, terdapat kecenderungan kenaikan numerik kandungan PK seiring dengan peningkatan umur panen. Chrisdiana (2018) melaporkan bahwa semakin lama umur panen akan meningkatkan kandungan PK sorghum yang ditanam secara hidroponik. Penjelasan lebih lanjut adalah adanya penurunan persentase fraksi karbohidrat yang digunakan selama pertumbuhan tanaman sehingga akan meningkatkan persentase PK. Akbag et al. (2014) juga menjelaskan bahwa selama perkecambahan dan pertumbuhan, tanaman menggunakan cadangan karbohidrat yang berasimilasi dengan aktivitas metabolismenya. Hal ini akan meningkatkan fraksi PK secara matematis. 
Penjelasan diatas juga dapat digunakan untuk menjelaskan mekanisme pola kandungan LK. Selain itu, kenaikan kandungan juga dapat dipengaruhi oleh produksi klorofil selama pertumbuhan. Fazaeli et al. (2012) menjelaskan bahwa kandungan LK green fodder berasosiasi dengan produksi klorofil yang mengiringi pertumbuhan tanaman.

Pola kenaikan NDF dan ADF semakin meningkat seiring bertambahnya umur panen. Hal tersebut sesuai dengan penelitian Chrisdiana (2018), Akbag et al. (2014), dan Fazaeli et al. (2012). Pada awal fase pertumbuhan tanaman, perkembangan fraksi serat sangat penting untuk mendukung metabolisme dan memperkokoh tegakan tanaman (lignin). Hal tersebut berasosiasi dengan kenaikan fraksi NDF dan ADF seiring dengan bertambahnya umur tanaman. Akumulasi peningkatan fraksi dinding sel berasosiasi dengan kandungan ADF dan NDF yang bertambah seiring dengan meningkatnya periode pemanenan (Akbag et al., 2014). Puteri et al. (2015) juga menjelaskan bahwa kandungan lignin akan semakin meningkat pada fase pemanenan yang lebih lama. Chrisdiana (2018) melaporkan bahwa akumulasi lignin juga dipengaruhi oleh frekuensi irigasi dan umur kematangan tanaman.

\section{Produksi Gas In Vitro}

Profil nutrisi yang berbeda pada Tabel 2 akan mempengaruhi produksi gas total dan $\mathrm{CH}_{4}$ secara in vitro (Tabel 3). Secara umum, SGF menghasilkan produksi gas total yang lebih tinggi dibandingkan rumput lapangan dari periode inkubasi ke-2 sampai 24 jam $(\mathrm{P}<0,05)$. Konsentrasi dan produksi $\mathrm{CH}_{4}$ SGF juga lebih rendah dibandingkan rumput lapangan $(\mathrm{P}<0,05)$. Konsentrasi dan produksi $\mathrm{CH}_{4}$ semakin meningkat seiring dengan meningkatnya umur panen SGF $(\mathrm{P}<0,05)$. Umur panen yang berbeda tidak berpengaruh terhadap produksi gas in vitro selama 24 jam inkubasi.

Akbag et al. (2014) menjelaskan bahwa produksi gas in vitro berkorelasi negatif dengan kandungan komponen dinding sel. Hal tersebut sesuai dengan hasil produksi gas SGF yang lebih tinggi dari rumput lapangan karena pengaruh rendahnya kandungan NDF serta ADF. Akan tetapi, perbedaan kandungan fraksi dinding sel antar perlakuan SGF tidak berpengaruh terhadap produksi gas secara in vitro. Hal tersebut dapat disebabkan oleh kandungan ADF yang relatif sama sejak umur pemanenan ke 8-10 hari. Efisiensi pemanfaatan nutrien yang dicerna dapat direpresentasikan oleh nilai konsentrasi dan produksi $\mathrm{CH}_{4}$. Dalam penelitian ini, rumput lapangan dan SGF 10 menghasilkan produksi $\mathrm{CH}_{4}$ tertinggi yaitu berturut-turut sebesar 3,57 dan 1,94 $\mathrm{ml} / 100 \mathrm{mg}$ KcBO . Tingginya produksi $\mathrm{CH}_{4}$ tersebut disebabkan oleh tingginya kandungan NDF pada kedua perlakuan tersebut. Kandungan $\mathrm{CH}_{4}$ akan semakin meningkat seiring meningkatnya kandungan hemiselulosa yang terdapat dalam NDF. Kandungan fraksi hemiselulosa akan meningkatkan proporsi asam asetat yang berasosiasi dengan penyediaan $\mathrm{H}_{2}$ dalam reaksi metanogenesis (Jayanegara et al., 2009).

Tabel 3. Produksi gas total dan konsentrasi $\mathrm{CH}_{4}$ rumput lapangan dan SGF

\begin{tabular}{|c|c|c|c|c|c|c|c|c|c|}
\hline \multirow{2}{*}{ Perlakuan } & \multicolumn{7}{|c|}{ Periode inkubasi (jam) } & \multirow[b]{2}{*}{$\% \mathrm{CH}_{4}$} & \multirow{2}{*}{$\begin{array}{c}\text { Produksi } \mathrm{CH}_{4} \\
(\mathrm{ml} / 100 \mathrm{mg} \\
\mathrm{KcBO})\end{array}$} \\
\hline & 2 & 4 & 6 & 8 & 10 & 12 & 24 & & \\
\hline Rumput lapangan & $5,62^{\mathrm{a}}$ & $9,08^{\mathrm{a}}$ & $14,64^{\mathrm{a}}$ & $20,85^{\mathrm{a}}$ & $27,44^{\mathrm{a}}$ & $32,55^{\mathrm{a}}$ & $49,21^{\mathrm{a}}$ & $10,30^{\mathrm{d}}$ & $3,57^{\mathrm{d}}$ \\
\hline SGF 7 & $13,84^{\mathrm{b}}$ & $20,06^{\mathrm{b}}$ & $25,29^{\mathrm{b}}$ & $30,89^{\mathrm{b}}$ & $37,99^{\mathrm{bc}}$ & $45,21^{b}$ & $78,10^{\mathrm{b}}$ & $3,79^{\mathrm{a}}$ & $1,26^{\mathrm{a}}$ \\
\hline SGF 8 & $13,69^{b}$ & $19,49^{b}$ & $24,45^{\mathrm{b}}$ & $29,77^{b}$ & $36,86^{\mathrm{b}}$ & $44,06^{\mathrm{b}}$ & $76,00^{\mathrm{b}}$ & $3,87^{\mathrm{a}}$ & $1,29^{\mathrm{a}}$ \\
\hline SGF 9 & $12,09^{\mathrm{b}}$ & $18,49^{\mathrm{b}}$ & $24,88^{\mathrm{b}}$ & $32,69^{b c}$ & $41,68^{\mathrm{cd}}$ & $48,28^{\mathrm{bc}}$ & $78,18^{\mathrm{b}}$ & $4,78^{b}$ & $1,53^{b}$ \\
\hline SGF 10 & $12,35^{\mathrm{b}}$ & $19,01^{\mathrm{b}}$ & $25,92^{\mathrm{b}}$ & $34,26^{\mathrm{c}}$ & $42,98^{\mathrm{d}}$ & $50,37^{\mathrm{c}}$ & $77,37^{\mathrm{b}}$ & $5,43^{c}$ & $1,94^{\mathrm{c}}$ \\
\hline SEM & 0,758 & 0,972 & 1,014 & 1,141 & 1,363 & 1,542 & 2,657 & 0,555 & 0,198 \\
\hline
\end{tabular}

SGF (Sorghum Green Fodder); SGF 7 (SGF yang dipanen pada umur 7 hari); SGF 8 (dipanen pada umur 8 hari); SGF 9 (dipanen pada umur 9 hari) dan SGF 10 (dipanen pada umur 10 hari); superskrip berbeda pada baris yang sama menunjukkan perbedaan yang nyata $(\mathrm{P}<0.05)$; SEM: Standard Error of the Means

\section{Produk Fermentasi Rumen}

Representasi proses fermentasi secara in vitro dapat dilihat pada Tabel 4. Kandungan $\mathrm{pH}$ yang dihasilkan oleh keempat perlakuan SGF lebih rendah dibandingkan rumput lapangan $(\mathrm{P}<0,05)$. Kandungan $\mathrm{pH}$ terendah dihasilkan oleh SGF yang 
dipanen pada hari ke-7 $(\mathrm{P}<0,05)$. Produksi $\mathrm{NH}_{3}$ sampel rumput lapangan lebih tinggi dibandingkan SGF $(\mathrm{P}<0,05)$. Produksi TVFA tertinggi dihasilkan oleh SGF yang dipanen pada hari ke-10 $(\mathrm{P}<0,05)$ namun tidak berbeda nyata dibandingkan dengan SGF 9dan rumput lapangan. Nilai EM dan KcBO keempat perlakuan SGF terlihat lebih tinggi dibandingkan rumput lapangan $(\mathrm{P}<0,05)$.

Kandungan $\mathrm{pH}$ terendah yang dihasilkan oleh perlakuan SGF 7 berasosiasi dengan rendahnya kandungan NDF dan ADF. Fraksi dinding sel yang rendah berasosiasi dengan tingginya kandungan karbohidrat yang mudah larut. Wahyono et al. (2017) melaporkan bahwa nilai $\mathrm{pH}$ yang rendah berasosiasi dengan tingginya kadar karbohidrat mudah larut dalam substrat. Konsentrasi $\mathrm{NH}_{3}$ dalam penelitian ini berkisar dari $7,56-10,15 \mathrm{mg} / 100 \mathrm{ml}$. Rataan nilai tersebut lebih tinggi dari standar rataan in vitro pada kultur tertutup yaitu $5 \mathrm{mg} / 100 \mathrm{ml}$ (Wanapat et al., 2013). Konsentrasi $\mathrm{NH}_{3}$ yang bervariasi dipengaruhi oleh Kandungan PK yang bervariasi pada tiap perlakuan (Tabel 2). Selain itu, tingkat degradasi protein dari masing-masing perlakuan juga berpengaruh. Jayanegara et al. (2016) melaporkan bahwa perbedaan kandungan protein yang terlarut, protein yang mudah terdegradasi, protein yang sulit terdegradasi dan protein yang tidak dapat terdegradasi akan mempengaruhi konsentrasi $\mathrm{NH}_{3}$ yang dihasilkan.

Produksi TFVA adalah salah satu parameter yang penting dalam percobaan kecernaan pakan karena TVFA merupakan sumber energi primer bagi ruminansia (Kondo et al., 2015). Nilai TVFA yang tinggi pada SGF 9, 10, dan rumput lapangan merepresentasikan tingkat kecernaan yang tinggi. $\mathrm{Hal}$ tersebut juga berasosiasi dengan produksi $\mathrm{CH}_{4}$ yang tinggi yang dihasilkan oleh ketigaperlakuan tersebut. Kondo et al. (2015) melaporkan bahwa nilai TVFA yang tinggi merepresentasikan tingginya tingkat kecernaan serat dan fraksi non fiber carbohydrate (NFC). Nilai EM dan $\mathrm{KcBO}$ SGF yang tinggi merepresentasikan nilai nutrisi yang tinggi dibandingkan rumput lapangan. Nilai nutrisi yang tinggi berasosiasi dengan rendahnya kadar NDF dan ADF SGF dibandingkan rumput lapang (Tabel 2). Nilai KCBO keempat perlakuan SGF berkisar antara 80,02-81,59\%. Zahera et al. (2015) melaporkan bahwa kecernaan tanaman pakan yang dibudidayakan secara hidroponik adalah sekitar 80\%. Fazaeli et al. (2012) melaporkan bahwa nilai KcBO barley green fodder adalah sekitar $81,86-85,53 \%$.

Tabel 4. Produk fermentasi rumen dan kecernaan bahan organik rumput lapangan dan SGF

\begin{tabular}{lllllll}
\hline \multirow{2}{*}{ Peubah fermentasi rumen } & \multicolumn{5}{c}{ Perlakuan } \\
\cline { 2 - 7 } & $\begin{array}{l}\text { Rumput } \\
\text { Lapangan }\end{array}$ & SGF 7 & SGF 8 & SGF 9 & SGF 10 & SEM \\
\hline $\mathrm{pH}$ & $6,65^{\mathrm{c}}$ & $6,51^{\mathrm{a}}$ & $6,53^{\mathrm{ab}}$ & $6,53^{\mathrm{ab}}$ & $6,54^{\mathrm{b}}$ & 0,012 \\
$\mathrm{NH}_{3}(\mathrm{mg} / 100 \mathrm{ml})$ & $10,15^{\mathrm{c}}$ & $7,56^{\mathrm{a}}$ & $8,12^{\mathrm{ab}}$ & $8,26^{\mathrm{ab}}$ & $8,61^{\mathrm{b}}$ & 0,221 \\
$\mathrm{TVFA}(\mathrm{mM})$ & $105,87^{\mathrm{ab}}$ & $86,80^{\mathrm{a}}$ & $100,24^{\mathrm{a}}$ & $124,69^{\mathrm{ab}}$ & $146,70^{\mathrm{b}}$ & 7,307 \\
$\mathrm{EM}(\mathrm{kkal} / \mathrm{kg} \mathrm{BK})$ & $2312,51^{\mathrm{a}}$ & $3249,39^{\mathrm{b}}$ & $3220,34^{\mathrm{b}}$ & $3279,36^{\mathrm{b}}$ & $3238,55^{\mathrm{b}}$ & 87,618 \\
$\mathrm{KcBO}(\%)$ & $55,36^{\mathrm{a}}$ & $80,74^{\mathrm{b}}$ & $80,02^{\mathrm{b}}$ & $81,59^{\mathrm{b}}$ & $80,52^{\mathrm{b}}$ & 2,379 \\
\hline
\end{tabular}

SGF (Sorghum Green Fodder); SGF 7 (SGF yang dipanen pada umur 7 hari); SGF 8 (dipanen pada umur 8 hari); SGF 9 (dipanen pada umur 9 hari) dan SGF 10 (dipanen pada umur 10 hari); $\mathrm{NH}_{3}$ (konsentrasi ammonia); TVFA (total volatile fatty acids); EM (energy termetabolis); KcBO (kecernaan bahan organik); superskrip berbeda pada kolom yang sama menunjukkan perbedaan yang nyata $(\mathrm{P}<0.05)$; SEM: Standard Error of the Means.

\section{KESIMPULAN}

Pola pertumbuhan, profil nutrisi dan kecernaan in vitro SGF semakin meningkat seiiring dengan meningkatnya umur pemanenan. Umur panen SGF yang terbaik adalah pada hari ke-9 dan 10 setelah penanaman. Hal tersebut direpresentasikan oleh tingginya nilai peubah berat segar, kandungan protein kasar, produksi gas dan KcBO. Akan tetapi, perlakuan SGF 10 juga menghasilkan produksi $\mathrm{CH}_{4}$ yang tinggisehingga SGF 10 tidak lebih baik daripada SGF 9. Perlu studi lanjutan untuk mengetahui efisiensi secara ekonomi penggunaan SGF sebagai pakan ruminansia. 


\section{UCAPAN TERIMA KASIH}

Penelitian ini merupakan bagian dari proyek Daftar Isian Penggunaan Anggaran (DIPA) laboratorium Nutrisi Ternak, Bidang Pertanian, Pusat Aplikasi Isotop dan Radiasi BATAN. Penulis mengucapkan terimakasih kepada Ir. Suharyono, M.Rur. Sci. dan Widia Apriliani, S.Si atas bantuan teknis selama penelitian berlangsung.

\section{DAFTAR PUSTAKA}

Akbag, H. I., O. S. Turkmen, H. Baytekin \& I. Y. Yurtman. 2014. Effects of harvesting time on nutritional value of hydroponic barley production. Turkish J. Agric. and Natural Sci. Special Issue (2):1761-1765.

AOAC. 2005. Official Method of Analysis. Maryland: Association of Official Analytical Chemists.

Blummel, B.Y.M., H. Steingass, \& K. Becker. 1997. The relationship berween in vitro gas production, in vitro microbial biomass yield and $15 \mathrm{~N}$ incorporated and its implication for the prediction of voluntary feed intake of roughages. Br. J. Nutr. 77:911-921.

Chrisdiana, R. 2018. Quality and quantity of sorghum hydroponic fodder from different varieties and harvest time. In IOP Conference Series: Earth and Environmental Science. Diponegoro University. Semarang.

Fazaeli, H., H.A. Golmohammadi, S.N. Tabatabayee, \& M. Asghari-Tabrizi. 2012. Productivity and nutritive value of barley green fodder yield in hydroponic system. World Appl. Sci. J. 16(4):531-539.

Jayanegara, A., S.P. Dewi, N. Laylli, E.B. Laconi \& M. Ridla. 2016. Determination of cell wall protein from selected feedstuffs and its relationship with ruminal protein digestibility in vitro. Med. Pet. 39 (2): 134140. https://doi.org/10.5398/medpet.2016. 39.2.134

Jayanegara, A., A. Sofyan, H.P.S. Makkar, \& K. Becker. 2009. Kinetika produksi gas, kecernaan bahan organik dan produksi gas metana in vitro pada hay dan jerami yang disuplementasi hijauan mengandung tanin.
Med. $\quad \begin{array}{rrr}\text { Pet. } & 32 & \text { (2): } 120-129 .\end{array}$ https://doi.org/10.5398/medpet. v32i2.1147

Kondo, M., M. Yoshida, M. Loresco, R. M. Lapitan, J. R. V. Herrera, A. N. D. Barrio, Y. Uyeno, H. Matsui \& T. Fujihara. 2015. Nutrient contents and in vitro ruminal fermentation of tropical grasses harvested in wet season in the Philippines. Adv. Anim. Vet. Sci. 3(12):694-699. http://dx.doi.org/ 10.14737/journal.aavs/2015/3.12.694.699

Koten, B. B., R. D. Soetrisno, N. Ngadiyono \& B. Soewignyo. 2014. Perubahan nilai nutrien tanaman sorgum (Sorghum bicolor (L.) Moench) varietas lokal rote sebagai hijauan pakan ruminansia pada berbagai umur panen dan dosis pupuk urea. Pastura 3(2):55-60.

Kumalasari, N. R., A.T. Permana, R. Silvia \& A. Martina. 2017. Interaction of Fertilizer, Light Intensity and Media on Maize Growth in Semi-Hydroponic System for Feed Production. In The $7^{\text {th }}$ International Seminar on Tropical Animal Production. Yogyakarta.

Lee, S. \& J. Lee. 2015. Beneficial bacteria and fungi in hydroponic systems: Types and characteristics of hydroponic food production methods. Sci. Hortic. 195:206215. https://doi.org/10.1016/j.scienta.2015. 09.011

Menke, K. H., L. Raab, A. Salewski, H. Steingass, D. Fritz \& W. Schneider. 1979. The estimation of the digestibility and metabolizable energy content of ruminant feedingstuffs from the gas production when they are incubated with rumen liquor in vitro. J. Agr. Sci-Cambridge. 93:217-222. https://doi.org/10.1017/S0021859600086305

Puteri, R. E., P. D. M. H. Karti, L. Abdullah \& Supriyanto. 2015. Productivity and nutrient quality of some sorghum mutant lines at different cutting ages. Med. Pet. 38(2):132137. https://doi.org/10.5398/medpet.2015. 38.2 .132

Steel, R.G.D. \& J.H. Torrie. 1960. Principles and Procedures of Statistics. McGraw. New York.

Van Soest, P.J., J.B. Robertson, \& B.A. Lewis. 1991. Methods for dietary fiber, neutral 
detergent fiber, and nonstarch polysaccharides in relation to animal nutrition. J. Dairy Sci. 74:3583-3597.

Wahyono, T., S.N.W. Hardani, \& I. Sugoro. 2018. Low irradiation dose for sorghum seed sterilization: hydroponic fodder system and in vitro study. Buletin Peternakan, 42(3): 215-221. https://doi.org/10.21059/buletin peternak.v42i3.30888
Zahera, R., I.G. Permana, \& Despal. 2015. Utilization of mungbean's green house fodder and silage in the ration for lactating dairy cows. Med. Pet. 38:123-131. https://doi.org/10.5398/medpet.2015.38.2.123 